\title{
Kinetic of on Nutrient Removal in Low-Strength Domestic Wastewater under Continuous Operation of Pilot Scale of Hybrid Reed Bed System (SF-VF-HF)
}

\author{
${ }^{1,3}$ Omar H. Jehawi, ${ }^{1,2}$ Siti Rozaimah S. Abdullah, ${ }^{1}$ Hassimi A. Hassan, \\ ${ }^{1,4}$ Nadya H. Al Sbani, ${ }^{1}$ Nur 'Izzati Ismail and ${ }^{3}$ Saleh O.A. Handi \\ ${ }^{1}$ Department of Chemical and Process Engineering, Faculty of Engineering and Built Environment, \\ ${ }^{2}$ Tasik Chini Research Center, Faculty of Science and Technology, Universiti Kebangsaan Malaysia, \\ 43600 UKM Bangi, Selangor, Malaysia \\ ${ }^{3}$ Higher Institute of Science and Technology, Al-Khums, Libya \\ ${ }^{4}$ Department of Chemical Engineering, Faculty of Oil and Gas Engineering, \\ Al Zawiya University, Zawiya, Libya \\ omerjehawi@yahoo.com
}

\begin{abstract}
Hybrid Reed Bed Constructed Wetland system (HRBCWs) for domestic wastewater treatment has been proven to be effective and as an alternative for conventional wastewater treatment technologies. Combination of constructed wetlands enhances pollutant removal efficiency as hybrid CWs could cover the limitation of each single (CWs). In our study, we employed a HRBCWs in three-stages, consisting of a Surface-Flow (SF) system followed by a Vertical-Flow (VF) system and finally by a Horizontal-Flow (HF) system. The system was planted with Scirpus grossus plant that could survive and reproduce with a continuous feed of $86.5 \mathrm{~L} /$ day of the raw wastewater. The results indicate that, the system with a 3 days HRT and different sizes of gravels can achieve average removal of $85 \% \mathrm{NH}_{4}-\mathrm{N}$ and $71 \% \mathrm{PO}_{4}-\mathrm{P}$. Also, the kinetic removal were investigated as absorbents in laboratory scale experimental, the results showed that the $\mathrm{q}_{e}, \mathrm{k}_{1}$ were found to be $132.68 \mathrm{mg} \mathrm{NH}_{4}-\mathrm{N} / \mathrm{g}$ biomass and $0.46 \mathrm{~d}^{1}$ for the surface flow system and $152.76 \mathrm{mg} \mathrm{NH} \mathrm{N}_{4} \mathrm{~N} / \mathrm{g}$ biomass and $0.53 \mathrm{~d}^{1}$ for the vertical flow system, respectively and $34.99 \mathrm{mg} \mathrm{NH}-\mathrm{N} / \mathrm{g}$ biomass and $0.35 \mathrm{~d} \cdot{ }^{1}$ for the horizontal flow system with a pseudo-first-order. The $\mathrm{NH}_{4}-\mathrm{N}$ biosorption by $\mathrm{SF}, \mathrm{VF}$ and $\mathrm{HF}$ were well fitted to the pseudo first-order plot with $\mathrm{R}^{2}$ of $0.99,0.98$ and 0.98 for $\mathrm{SF}, \mathrm{VF}$ and $\mathrm{HF}$, respectively. The planted HRBCW system shows a better performance than the unplanted system. These results indicate that the HRBCW system using Scirpus grossus plant has a high effectiveness for treating domestic wastewater.
\end{abstract}

Key words: Hybrid Reed Bed Constructed Wetland ( $\mathrm{HRBCW}$ ) system, domestic wastewater, kinetic removal, phytoremediation, Surface-Flow (SF), Vertical-Flow (VF)

\section{INTRODUCTION}

Constructed wetlands are artificial design for wastewater treatment systems which have been planted with aquatic plants and which rely upon natural microbial, biological, physical and chemical processes to treat wastewater use rooted wetland plants with courage media to provide the treatment process (Kadlec and Knight, 1996). As well as the green technology, contaminant treatment systems such as Constructed Wetland systems (CWs) have the competitive advantage of producing greater quality without having the input of fossil energy power thereby impair the treatment operation charge (Sim et al., 2007; Lee et al., 2010 and Bruch et al., 2011).

Actually, there are two basic types of constructed wetlands; Surface Flow (SF) and Sub-Surface Flow (SSF) systems (Kadlec and Knight, 1996). SF systems are similar to natural wetlands with shallow flow of wastewater (usually $<60 \mathrm{~cm}$ deep) over saturated media substrate. SSF systems mostly employ gravel as the main media to support the growth of plants, wastewater flows vertically or horizontally through the substrate where it comes into contact with microorganisms, living on the surfaces of

Corresponding Author: Omar H. Jehawi, Department of Chemical and Process Engineering,

Faculty of Engineering and Built Environment, Universiti Kebangsaan Malaysia, 43600 UKM Bangi,

Selangor, Malaysia, omerjehawi@yahoo.com 
plant roots and substrate (Cooper 1996; Kadlec and Knight, 1996) allowing pollutant removal from the bulk liquid. SSF constructed wetlands are further divided into two types: Vertical Flow (VF) and Horizontal Flow (HF) systems, both are typically more effective than the Surface systems (SF) in terms of mass pollutant removal per $\mathrm{m}^{2}$ of surface area system (Luederitz et al., 2001; Ruan et al., 2006; Vymazal et al., 2006 and Vymazal, 2007). There are many types of contaminants in the human water use (like: phosphorus, nitrogen, heavy metals, organics, suspended solids and cadmium), removal can be achieved by using combined constructed wetlands, through a complicated system of plants, media, microbial activity and bio-mass population (Fountoulakis et al. 2009). Nitrogen and organics contaminants removal from domestic wastewater in such designed human ecosystems is globally important because there was an uncontrolled discharge of nutrients wastewater into natural water bodies like river, ponds and ocean (Xinshan et al., 2010; Chen et al., 2011). The literature affirmed that effective removal of organics contaminants in SSF system compared to SF system, nonetheless as a result, producers from these systems for reducing nitrogen rates are often weak (Vymazal et al., 2006).

Recently, a combination of VF and HF systems, known as hybrid system can be also, employed for the treatment of domestic wastewater. Such combinations often optimize nitrogen and organics removal due to presence of aerobic, anaerobic and anoxic phases (Vymazal, 2005; Kadlec and Wallace, 2009). Organic compounds can be degraded aerobically and anaerobically in SSF systems. Oxygen for aerobic treatment can be supplied via. atmospheric oxygen diffusion, convection (wind effect) and/or macrophyte root transfer into the plant rhizosphere (Cooper, 1996). Anaerobic (lacking oxygen) organics removal can proceed inside the media pores.

Nowadays, a human design of household removal have become a very popular treatment technologies (Obarska-Pempkowiak and Klimkowska, 1999). These systems considered as low-cost alternative for human water use treatment, especially, suitable for developing countries. They also have low operation and maintenance requirements (Wittgren and Maehlum, 1997). They have been proved to be efficient in reducing different undesired constituents such as nitrogen and organics contaminants from household wastewaters. Biochemical transformations, adsorptions, precipitations, volatilization and plant uptake of pollutants are the main pollutant removal mechanism in a constructed wetlands system
(Inamori et al., 2007). Constructed wetland is principally using the same natural degradation processes and nutrient uptake.

Scirpus grossus was used in this study due to its potential as a tolerance plant (Tangahu et al., 2013). This plant has fibrous roots in white to brown color, triangular and solid stems, more than $2 \mathrm{~m}$ long leaves with bisexual flowers grouped together. It is a perennial tropical aquatic plant, the common names are Giant bulrush, Greater club rush and Rumput menderong in Malaysia. It is an aquatic perennial plant which is widely used to treat domestic wastewater in phytoremediation or wetland treatment (Jinadasa et al., 2008).

A large number of physical, chemical and biological processes are involved in these systems influencing each other (Langergraber et al., 2009) which are not fully understood to date due to lack of appropriate models. As far as first order kinetics is considered, Lagergren equation seems to be the most widely applied equation. This equation was the first rate equation for the sorption of liquid-solid systems based on solid capacity (Wang et al., 2010). A study on the characteristic curves of this equation showed that Lagergren equation can yield superior correlation with the sorption data over the pseudo second order kinetics for a number of sorption systems (Tseng et al., 2010). Another important observation regarding Lagergren equation is that it correlates better data in the adsorption systems that are not far from equilibrium (Rudzinski and Plazinski, 2007). The aims of this study were to evaluate the kinetic of ammonia-nitrogen $\left(\mathrm{NH}_{4}-\mathrm{N}\right)$ removal in low-strength domestic wastewater under continuous operation of pilot scale of combination Hybrid Reed Bed Constructed Wetland systems (HRBCWs) and find an appropriate model for the kinetics of removal.

\section{MATERIALS AND METHODS}

\section{Design of Hybrid Reed Beds Constructed Wetland systems (HRBCWs): Hybrid Reed Beds Constructed Wetland ( $\mathrm{HRBCW}$ ) system is an engineering design that can be used for single family houses or for small communities. In current study, a HRBCW system Fig. 1 containing of three similar tanks that are combined to each other's and all tanks material were constructed from fiber glass $\left(1 \mathrm{~m}, \mathrm{~W}^{*} 2 \mathrm{~m}, \mathrm{~L}^{*} 1 \mathrm{~m}, \mathrm{D}\right)$ with a PVC pipe. Gravels-sand-gravel were used as media of these systems and arranged with 10-15, 3-5 mm (river sand) and $30-35 \mathrm{~mm}$ diameter of media, respectively, from the top of each thank to down layer to draw nutrients from domestic}




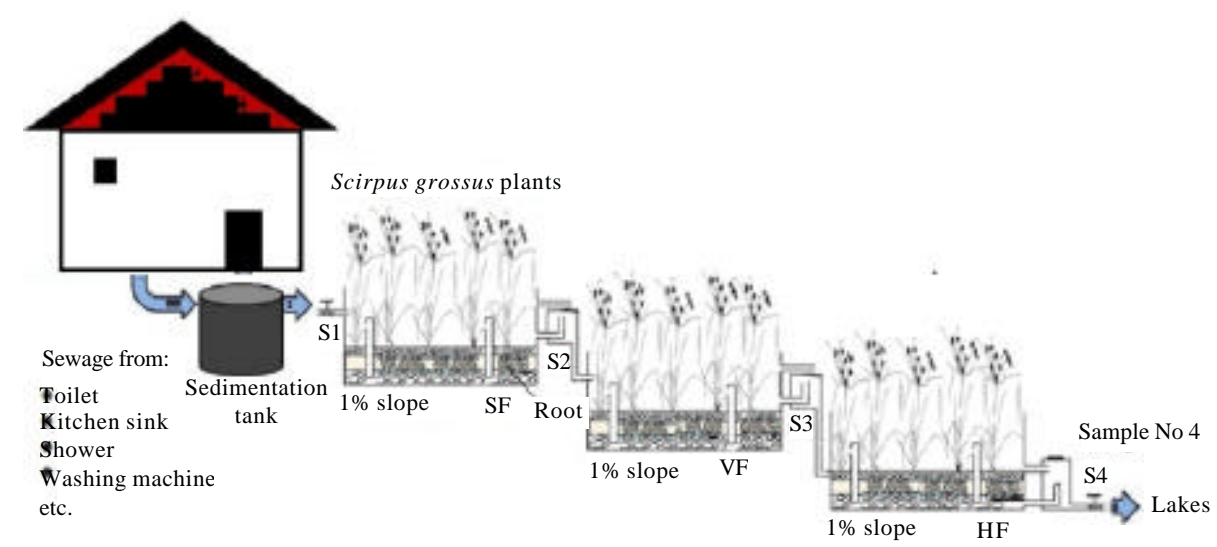

Fig. 1: Schematic layout of HRBCW systems: a) Side view and b) Plan view

wastewater. All tanks were filled with the mixture media to depth around $40 \mathrm{~cm}$ and provided Surface Flow (SF) and Vertical Flow (VF) systems with oxygen by pumping pipe. Domestic wastewater level in the sub-surface flow system was $10 \mathrm{~cm}$ below the surface of the media and $>15 \mathrm{~cm}$ for the surface flow system. All tanks were planted with Scripus grossus by installing HRBCW systems entailing putting the operating system in continuous process to find out the feasibility of this combined systems to eliminate nutrients from household wastewater.

The domestic wastewater of the Bukit Putri effluent of primary was pumped into the sedimentation tank and then distributed to two HRBCW systems. Scirpus grossus was planted in the first three series systems (HRBCWs). In the second three series systems, there were control HRBCW system with the gravels-sand-gravels as a media and without vegetation plant. The influent flow rate of each HRBCW system was $86.5 \mathrm{~L} /$ day with continuous feed of the household sewage and 3 days HRT. During the course of the experiments ( 4 months), sewage samples were collected every week from the influent and effluents of HRBCW systems and were measured in the laboratory of the Engineering Faculty of UKM campus.

Sampling analysis: Samples of the sewage wastewater treatment were collected every week depending on the sheet time of study and basis from outlet zone as well as at distances of $2 \mathrm{~m}$ from inlet to the outlet in each tank at a depth of $0.15 \mathrm{~m}$ below the surface for sub-surface flow system and up to $0.15 \mathrm{~m}$ for surface flow system. Samples were taken from the end of each tank, then, the samples were immediately analyzed for the parameters. The test of ammonia-nitrogen, nitrate-nitrogen and phosphorus are carried, according to standard method of water and wastewater which is approved by EPA. The test was conducted using DR3900 HACH machine.
Statistical analysis: Statistical analysis using the two-way ANOVA (Analysis of Variance) on the performance of HRBCW systems in terms of nutrients removal was carried out using Statistical Package for the Social Sciences (SPSS), Statistics 21.

Ammonia-nitrogen uptake: The $\mathrm{NH}_{4}-\mathrm{N}$ uptake by the plant was calculated using the following Eq. 1 (Vieira and Volesky, 2000):

$$
\mathrm{q}_{\mathrm{e}}=\frac{\mathrm{V}\left(\mathrm{C}_{\mathrm{i}}-\mathrm{C}_{\mathrm{e}}\right)}{\mathrm{X}}
$$

Where:

$\mathrm{q}_{\mathrm{e}}=$ The $\mathrm{NH}_{4}-\mathrm{N}$ uptake (mg $\mathrm{NH}_{4}-\mathrm{N} / \mathrm{g}$ biomass)

$\mathrm{V}=$ The Volume of the sewage wastewater (L)

$\mathrm{C}_{\mathrm{i}}=$ The influent Concentration of $\mathrm{NH}_{4}-\mathrm{N}$ in the solution $\left(\mathrm{mg} \mathrm{NH} \mathrm{NH}_{4}-\mathrm{N} / \mathrm{L}\right)$

$\mathrm{C}_{\mathrm{e}}=$ The effluent Concentration of $\mathrm{NH}_{4} \mathrm{~N}$ in the sewage wastewater ( $\mathrm{mg} \mathrm{NH}_{4}-\mathrm{N} / \mathrm{L}$ )

$\mathrm{X}=$ The dry weight of the biomass $(\mathrm{g})$

Kinetics removal: In this study, kinetics removal was described using the first order equation of Lagergren and the pseudo second-order equation (Ho and McKay, 1999). The sorption kinetic provides valuable insights into the reaction pathways and the mechanism of a sorption reaction. The pseudo-first order model is used to describe the sorption kinetics (Ho and McKay, 1999). The model is based on the assumption that the adsorption follows first order chemisorption's and predicts the behavior over the whole range of concentration and is in agreement with an adsorption mechanism being the controlling step rate. This kinetic model is represented as Eq. 2 (Yuan et al., 2009):

$$
\log \left(q_{e}-q_{t}\right)=\log q_{e}-\frac{k_{1} t}{2.303}
$$


where, $\mathrm{q}_{\mathrm{t}}$ and $\mathrm{q}_{\mathrm{e}}$ are the $\mathrm{NH}_{4}-\mathrm{N}$ uptake on the biosorbent at any time and at equilibrium ( $\mathrm{mg} \mathrm{NH}_{4}-\mathrm{N} / \mathrm{g}$ biomass), $\mathrm{k}_{1}$ is the rate constant of Lagergren first-order biosorption $\left(\mathrm{d}^{-1}\right)$. The straight-line plot of $\log \left(\mathrm{q}_{\mathrm{e}}-\mathrm{q}_{\mathrm{t}}\right)$ against $\mathrm{t}$ gives $\log \left(\mathrm{q}_{\mathrm{e}}\right)$ as slope and intercept equal to $k_{1} / 2.303$. Hence, the amount of solute sorbed per gram of sorbent at equilibrium $\left(\mathrm{q}_{\mathrm{e}}\right)$ and the first-order sorption rate constant $\left(k_{1}\right)$ can be evaluated from the slope and the intercept.

\section{RESULTS AND DISCUSSION}

Nutrients removal: There are three types of nutrient analyzed in this study that is $\mathrm{NH}_{4}-\mathrm{N}, \mathrm{NO}_{3} \mathrm{~N}$ and $\mathrm{PO}_{4} \mathrm{P}$. The high $\mathrm{NH}_{4}-\mathrm{N}$ content was mainly due to the fact that after $\mathrm{NH}_{4}-\mathrm{N}$ was formed by ammonification (Ehrig and Stegmann, 1992). Phosphorus is the most important nutrient enhancing eutrophication in lakes and coastal waters (Klapper, 1992). Therefore, phosphorus must be removed largely by HRBCW systems of treatment.

Ammonia-nitrogen $\left(\mathrm{NH}_{4}-\mathrm{N}\right)$ removal: Figure 2 shows the overall performance of $\mathrm{NH}_{4}-\mathrm{N}$ removal for both the $\mathrm{HRBCW}$ systems (planted and control). Influent concentration for HRBCW system (SF-VF-HF) ranges from $5.60-8.15 \mathrm{mg} / \mathrm{L}$ while the effluent concentration ranges from $0.23-2.96 \mathrm{mg} / \mathrm{L}$ in the planted systems and

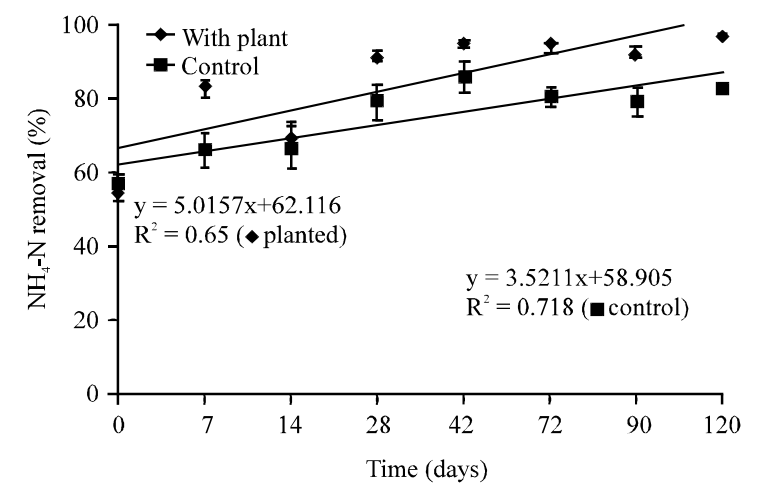

Fig. 2: Removal efficiency of $\mathrm{NH}_{4}-\mathrm{N}$ in planted and control HRBCW systems (SF-VF-HF)
0.97-2.80 $\mathrm{mg} / \mathrm{L}$ in control systems. The removal efficiency ranges from $36-81 \%$ for planted systems and $40-62 \%$ for control systems. The results indicated that control HRBCW system have lower removal efficiency as compared to planted HRBCW system. Table 1 illustrates the correlation between removal efficiency with time of treatment with correlation coefficient $\left(\mathrm{R}^{2}\right)$ that ranged from $0.58-0.88$. This shows that removal efficiency percentages are increases with increase time of treatment. Generally, it shows that better $\mathrm{NH}_{4}-\mathrm{N}$ removal are obtained in planted systems when compared to the control systems.

The $\mathrm{NH}_{4}-\mathrm{N}$ mean removal values are showed in $\mathrm{VF}$ and $\mathrm{HF}$ flow systems were more reliable than the SF flow system which was also, noted by the USEPA because in sub-surface flow system ( $\mathrm{VF}$ and $\mathrm{HF}$ ), water must remain below the media surface to minimize human contact.

Decomposition and mineralization processes in the wetlands will convert a significant part of organic- $\mathrm{N}$ to ammonia. The source of ammonia is believed to be from the anaerobic decomposition of the organic-N trapped in the bed as particulate matter. Biological nitrification followed by denitrification is believed to be the major contribution towards ammonia removal in constructed wetlands (Reed, 1993). Vertical and horizontal flow system which is planted by Scirpus grossus shows a better removal as compared to the control system. This is because Scirpus grossus has long penetrating roots to enhance removal efficiency of $\mathrm{NH}_{4}-\mathrm{N}$.

Based on statistical analysis at 5\% level of significance, it was found that effluent ammonia concentrations ranged from $3.57-5.37 \mathrm{mg} / \mathrm{L}$ for the surface flow system, the ammonia removal efficiency of the planted system was generally, higher than the control system. Maximum ammonia removal efficiency for the planted system was $45.9 \%$ while maximum efficiency for the control system was $38.9 \%$. For the vertical flow in the HRBCW system, it was found that effluent ammonia concentrations ranged from $0.72-3.1 \mathrm{mg} / \mathrm{L}$, ammonia removal efficiency for planted system was higher than of the control system. Maximum ammonia removal efficiency for planted system was $80.8 \%$ while that for the control

Table 1: Correlation between removal efficiency with time of treatment for $\mathrm{NH}_{4}-\mathrm{N}$

\begin{tabular}{|c|c|c|c|}
\hline Flow types/Systems & Equations & Correlation coefficient $\left(\mathrm{R}^{2}\right)$ & Removal (\%) \\
\hline \multicolumn{4}{|l|}{ Surface Flow (SF) } \\
\hline With plant & $y=2.4833 x+28.025$ & 0.67 & 39.20 \\
\hline Control & $y=2.7524 x+18.105$ & 0.74 & 30.49 \\
\hline \multicolumn{4}{|l|}{ Vertical Flow (VF) } \\
\hline With plant & $y=5.0868 x+43.324$ & 0.58 & 66.21 \\
\hline Control & $y=2.5927 x+40.5$ & 0.69 & 52.17 \\
\hline \multicolumn{4}{|l|}{ Horizontal Flow (HF) } \\
\hline With plant & $\mathrm{y}=8.985 \mathrm{x}+0.3948$ & 0.88 & 40.83 \\
\hline Control & $y=2.9222 x+14.176$ & 0.61 & 27.33 \\
\hline HRBCW system & & & \\
\hline $\begin{array}{l}\text { With plant } \\
\text { (SF-VF-HF) }\end{array}$ & $y=5.0157 x+62.116$ & 0.65 & 84.69 \\
\hline Control & $\mathrm{y}=3.5211 \mathrm{x}+58.905$ & 0.72 & 74.75 \\
\hline
\end{tabular}


Table 2: The pseudo first-order kinetic constants of Lagergren for HRBCW sy stems

\begin{tabular}{|c|c|c|c|c|}
\hline \multirow[b]{2}{*}{ Systems } & \multirow{2}{*}{$\begin{array}{c}\text { Experimental results } \\
\mathrm{q}_{\mathrm{e}}\left(\mathrm{mg} \mathrm{NH}_{4}-\mathrm{N} / \mathrm{g} \text { biomass }\right)\end{array}$} & \multicolumn{3}{|c|}{ Pseudo first-order of Lagergren } \\
\hline & & $\mathrm{q}_{\mathrm{e}}\left(\mathrm{mg} \mathrm{NH}_{4} \mathrm{~N} / \mathrm{g}\right.$ biomass $)$ & $\mathrm{k}_{1}\left(\mathrm{~d}^{-1}\right)$ & Error $(\%)$ \\
\hline SF & 134.98 & 132.68 & 0.46 & 1.71 \\
\hline $\mathrm{VF}$ & 159.59 & 152.75 & 0.53 & 4.28 \\
\hline $\mathrm{HF}$ & 36.35 & 34.99 & 0.35 & 3.73 \\
\hline
\end{tabular}

$\mathrm{k}_{1} ;$ Pseudo-first-order kinetic constant of $\mathrm{NH}_{4}-\mathrm{N} ; \mathrm{q}_{\mathrm{e}}$ Adsorption amount from pseudo-first-order equation; $\mathrm{q}_{\mathrm{e}}$; Experimental: adsorption amount from experiment data

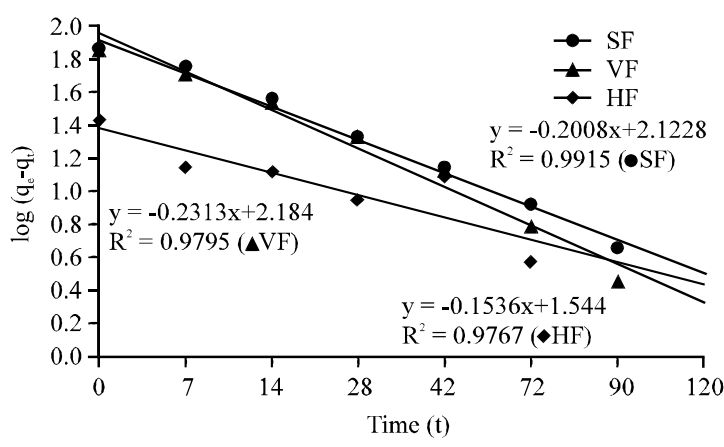

Fig. 3: The first-order of Lagergren plot for $\mathrm{NH}_{4}-\mathrm{N}$ biosorption

system was only $61.4 \%$. For the horizontal flow system, it was found that effluent ammonia concentrations ranged $0.23-2.96 \mathrm{mg} / \mathrm{L}$, ammonia removal efficiency for the planted system was higher than that of the control system. Maximum ammonia removal efficiency for planted system was $70.9 \%$ while the maximum efficiency for control was $40.1 \%$ throughout the study period. The p-value was statistically significant between removal with (planted and control) systems of exposure and also, used two-way ANOVA test to analyze the percentage of $\mathrm{NH}_{4}-\mathrm{N}$ removal in the HRBCW system and to explain the interaction between parameters involved. Percentage of $\mathrm{NH}_{4}-\mathrm{N}$ removal was statistically significant with systems of exposure with $\mathrm{p}<0.05$. The two-way ANOVA test also, showed insignificant interactions with $\mathrm{p}<0.05$ between (day and removal) (hybrid system and removal) and (day*hybrid system*removal). The results showed that the HRBCW system in this study has a high efficiency in removing $\mathrm{NH}_{4}-\mathrm{N}$ from the domestic wastewater.

$\mathrm{NH}_{4}-\mathrm{N}$ kinetics removal: Figure 3 showed a pseudo-first-order of Lagergren plot for $\mathrm{NH}_{4}-\mathrm{N}$ biosorption on HRBCW system. The $\mathrm{q}_{\mathrm{e}}$ and $\mathrm{k}_{1}$ obtained from the respective intercept and slope of Eq. 2 were found to be $132.68 \mathrm{mg} \mathrm{NH}_{4}-\mathrm{N} / \mathrm{g}$ biomass and $0.46 \mathrm{~d} \cdot{ }^{1}$ for the surface flow system and $152.76 \mathrm{mg} \mathrm{NH}_{4}-\mathrm{N} / \mathrm{g}$ biomass and $0.53 \mathrm{~d} \cdot{ }^{1}$ for the vertical flow system, respectively, also, $34.99 \mathrm{mg} \mathrm{NH}-\mathrm{N} / \mathrm{g}$ biomass and $0.35 \mathrm{~d} \bullet^{1}$ for the horizontal flow system with a pseudo-first-order. As shown in Table 2, the calculated $\mathrm{q}_{\mathrm{e}}$ values for $\mathrm{SF}, \mathrm{VF}$ and
HF demonstrated lower errors $(<5 \%)$ when compared with the experimental $\mathrm{q}_{\mathrm{e}}$. The obtained $\mathrm{q}_{\mathrm{e}}$ was $134.98 \mathrm{mg}$ $\mathrm{NH}_{4}-\mathrm{N} / \mathrm{g}$ biomass, $159.59 \mathrm{mg} \mathrm{NH}_{4} \mathrm{-N} / \mathrm{g}$ biomass for $\mathrm{SF}$ and VF systems, respectively. Also, getting $36.35 \mathrm{mg} \mathrm{NH}_{4}-\mathrm{N} / \mathrm{g}$ biomass for $\mathrm{HF}$ system.

However, the $\mathrm{NH}_{4}-\mathrm{N}$ biosorption by HRBCW systems were well fitted to the pseudo first-order plot with $\mathrm{R}^{2}$ of $0.99,0.98$ and 0.98 for $\mathrm{SF}, \mathrm{VF}$ and $\mathrm{HF}$, respectively, suggesting that the pseudo first-order was favourable to describe the biosorption mechanism of $\mathrm{NH}_{4}-\mathrm{N}$ by $\mathrm{SF}, \mathrm{VF}$ and $\mathrm{HF}$. Moreover, higher $\mathrm{k}_{1}$ values for $\mathrm{VF}$ than those of $\mathrm{SF}$ and HF proved that vertical flow system is much better for $\mathrm{NH}_{4}-\mathrm{N}$ biosorption.

Nitrate $\left(\mathrm{NO}_{3}-\mathbf{N}\right)$ removal: The overall results show inlet and outlet of $\mathrm{NO}_{3}-\mathrm{N}$ concentration in HRBCW systems. Influent concentration ranges from $0.1-0.5 \mathrm{mg} / \mathrm{L}$ while the effluent concentration for surface flow system ranges from $0.72-1.69 \mathrm{mg} / \mathrm{L}$ in planted systems and $0.61-1.11 \mathrm{mg} / \mathrm{L}$ in HRBCW control system. Effluent concentrations from the vertical and horizontal constructed wetland system ranges from $2.10-3.49 \mathrm{mg} / \mathrm{L}, 1.67-2.79$ in planted systems and $1.39-1.63,1.14-1.58 \mathrm{mg} / \mathrm{L}$ in control systems, respectively.

The major removal mechanism of $\mathrm{NO}_{3}-\mathrm{N}$ is due to the processes such as ammonification, nitrification and denitrification. Ammonia is oxidized to nitrate by nitrifying bacteria in aerobic zones. Nitrates are converted to nitrogen gas $\left(\mathrm{N}_{2}\right)$ and Nitrous Oxide $\left(\mathrm{N}_{2} \mathrm{O}\right)$ by denitrifying bacteria in anoxic zones. To do nitrification process, oxygen is needed and it is supplied by diffusion from the air pump and also, from the macrophytes roots. $\mathrm{NO}_{3}-\mathrm{N}$ is not only removed through these processes, it is also, taken up by plants and turned to biomass and released back as organic nitrogen after decomposition of the plants.

Phosphorus ( $\left.\mathbf{P O}_{4}-\mathbf{P}\right)$ removal: Figure 4 shows the overall performance of phosphorus removal for both the $\mathrm{HRBCW}$ systems (planted and control). Influent concentration ranges from $2.54-3.22 \mathrm{mg} / \mathrm{L}$. Effluent concentrations in the surface flow system ranges from $1.69-2.78 \mathrm{mg} / \mathrm{L}$ for planted system and $2.14-3.08 \mathrm{mg} / \mathrm{L}$ in control system. Also, for sub-surface flow systems, ranges from 0.76- 2.38, $0.34-2.10 \mathrm{mg} / \mathrm{L}$ in planted systems and 1.19-1.71, $0.58-2.42 \mathrm{mg} / \mathrm{L}$ in control systems for vertical and 
Table 3: Correlation between removal efficiency with time of treatment for $\mathrm{PO}_{4}-\mathrm{P}$

\begin{tabular}{|c|c|c|c|}
\hline Flow type/Systems & Equations & Correlation coefficient $\left(\mathrm{R}^{2}\right)$ & Removal (\%) \\
\hline \multicolumn{4}{|l|}{ Surface Flow (SF) } \\
\hline With plants & $y=3.3288 x+14.411$ & 0.93 & 29.39 \\
\hline Control & $y=1.9006 x+7.9217$ & 0.73 & 16.47 \\
\hline \multicolumn{4}{|l|}{ Vertical Flow (VF) } \\
\hline With plants & $y=5.5374 x+14.05$ & 0.95 & 38.97 \\
\hline Control & $y=4.0778 x+14.612$ & 0.90 & 32.96 \\
\hline \multicolumn{4}{|c|}{ Horizontal Flow (HF) } \\
\hline With plants & $y=6.2698 x+10.846$ & 0.93 & 39.06 \\
\hline Control & $y=5.8711 x+6.3186$ & 0.96 & 32.74 \\
\hline \multicolumn{4}{|l|}{ HRBCW systems } \\
\hline $\begin{array}{l}\text { With plants } \\
\text { (SF-VF-HF) }\end{array}$ & $y=6.8155 x+40.308$ & 0.87 & 70.98 \\
\hline Control & $y=6.8102 x+29.795$ & 0.87 & 60.44 \\
\hline
\end{tabular}

Table 4: A comparison of the removal efficiency of the different flow systems in HRBCWs with other studies in different countries

\begin{tabular}{|c|c|c|c|c|c|c|}
\hline $\begin{array}{l}\text { Flow sy stem/ } \\
\text { Location of pilot system }\end{array}$ & $\begin{array}{l}\mathrm{NH}_{4}-\mathrm{N} \\
(\%) \text { Rem }\end{array}$ & $\begin{array}{l}\mathrm{NO}_{3}-\mathrm{N} \\
(\%) \text { Rem }\end{array}$ & $\begin{array}{l}\mathrm{PO}_{4}-\mathrm{N} \\
(\%) \text { Rem }\end{array}$ & $\begin{array}{l}\text { HRT } \\
\text { days }\end{array}$ & $\begin{array}{l}\text { Plant type in } \\
\text { the pilot system }\end{array}$ & References \\
\hline \multicolumn{7}{|l|}{ SF } \\
\hline Taihu, China & 22.8 & 34.2 & 35.1 & - & Typha angustifolia & Li et al. (2008) \\
\hline Putrajay a, Malay sia & - & 70.7 & 84.3 & - & Lepironia artic ulata & Simetal. (2007) \\
\hline Petchaburi, Tailand & 75.4 & - & 44.9 & 5 & Typha angustifolia & Klomjek and Nitisoravut (2005) \\
\hline Nyanza, Kenya & 36 & - & 29 & - & Cyperus popyrus & Bojcevska and Tonderski (2007) \\
\hline Bangi, Malaysia & 39.2 & - & 29.39 & 3 & Scirpus grossus & This study in 2018 \\
\hline \multicolumn{7}{|l|}{ VF } \\
\hline Longdao, Beijing & 10.5 & - & 30.6 & - & Phragmites australis & Chen et al. (2008) \\
\hline Wuxi, China & 61.7 & - & 48.9 & - & Phragmites typhia & He et al. in 2006 \\
\hline Ankara, Turkey & 57.86 & - & 4.19 & - & Phragmites australis & Korkusuz et al. (2004) \\
\hline Chalkidiki, North Greece & 49.6 & - & 17.9 & 2 & Phragmites australis & Gikas et al. (2007) \\
\hline Bangi, Malaysia & 66.21 & - & 38.97 & 3 & Scirpus grossus & This study in 2018 \\
\hline \multicolumn{7}{|l|}{ HF } \\
\hline Pingtung County, Taiwan & 22.16 & 54 & 32.14 & 8.5 & Eichhornia crassipes & Lee et al. (2004) \\
\hline Barcelona, North-East Spain & 30.1 & - & 58.33 & 5.5 & (Phragmites australis & Garcia et al. (2004) \\
\hline Juja, Nairobi city, Kenya & 17.13 & 22 & 57.14 & - & Cyperus popyrus & Mburu et al. (2012) \\
\hline Dar es Salaam, Tanzania & 23.01 & 44.3 & - & - & Typha latifolia & Kaseva (2004) \\
\hline Bangi, Malaysia & 40.83 & - & 39.06 & 3 & Scirpus grossus & This study in 2018 \\
\hline
\end{tabular}

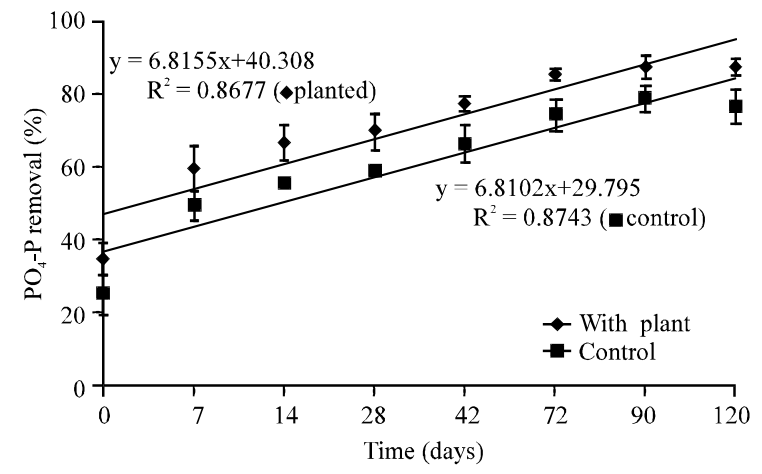

Fig. 4: Removal efficiency of $\mathrm{PO}_{4}-\mathrm{P}-\mathrm{N}$ in (planted and control) HRBCW systems (SF-VF-HF)

horizontal flow systems, respectively, resulting in high removal rates that were largely dependent on inlet concentration. The phosphorus removal efficiency of surface flow system is ranged from $13.7-38 \%$ for planted systems and 4.3-21\% for control system. For vertical and horizontal flow systems, the removal ranges from 14.4-55 and $11.8-55.4 \%$ for planted systems and $12.7-44.4 \%, 10-51.3 \%$ for control systems, respectively.
The results showed that the control system has lower removal efficiency as compared to planted system. Removal efficiency in planted systems for HRBCW systems reaches up to $87 \%$ where else removal efficiency for HRBCW control system is only $78.6 \%$. The efficiency of the process decreases slowly towards the end of the experimental period (Fig. 4).

Table 3 illustrates the correlation between removal efficiency with time of treatment with correlation coefficient $\left(\mathrm{R}^{2}\right)$ from $0.73-0.96$. This shows that removal efficiency percentages are increases with increase time of treatment. A comparison of the removal efficiency of the different flow systems in HRBCWs with other studies in different countries was carried out in Table 4. As illustrated in Table 3 , the removal efficiencies of $\mathrm{NH}_{4} \mathrm{~N}$ are better compared to those of the other CW systems.

Based on statistical Analysis of Variance (ANOVA) at $5 \%$ level of significance, the p-value was statistically significant between removal with (planted and control) HRBCW systems of exposure and also used two-way ANOVA test to analyze the percentage of $\mathrm{PO}_{4}-\mathrm{P}$ removal in the HRBCW systems and to explain the interaction between parameters involved. Percentage of $\mathrm{PO}_{4}-\mathrm{P}$ 
removal was statistically significant with $\mathrm{p}<0.05$. The two-way ANOVA test also showed the interactions with $\mathrm{p}<0.05$ between (day* removal) (hybrid system* removal) and (day*hybrid system*removal). The results showed that the HRBCW system in this study has a high efficiency in removing $\mathrm{PO}_{4}-\mathrm{P}$ from the domestic wastewater.

\section{CONCLUSION}

The HRBCW systems for different flow direction beds had significantly higher performance during the wetlands operational period for nutrients pollutants treatment. Removal efficiency of this study did show an effective performance as predicted. Presence of Scirpus grossus did increase the ability of the HRBCW systems to decrease the level of nutrients as showed in the results.

Kinetic data for $\mathrm{NH}_{4}-\mathrm{N}$ adsorption onto the various adsorbents were fitted to pseudo first-order Lagergren and pseudo second-order to investigate the mechanism of adsorption. The Lagergren second-order (calculations not shown) was ruled out because its regression was not significant. Hence, $\mathrm{NH}_{4}-\mathrm{N}$ removal by the adsorbents did not follow the Lagergren second order kinetics. The first-order fitted the experimental data well with a correlation coefficient for the HRBCWs $\left(\mathrm{R}^{2}>0.95\right)$.

\section{ACKNOWLEDGEMENTS}

The researchers would like to thank Universiti Kebangsaan Malaysia, Tasik Chini Research Centre and Malaysian Ministry of Science, Technology and Innovation for supporting this research project under a Research Grant of 02-01-02-SF1045.

\section{REFERENCES}

Bojcevska, H. and K. Tonderski, 2007. Impact of loads, season and plant species on the performance of a tropical constructed wetland polishing effluent from sugar factory stabilization ponds. Ecol. Eng., 29: 66-76.

Bruch, I., J. Fritsche, D. Banninger, U. Alewell and M. Sendelov et al., 2011. Improving the treatment efficiency of constructed wetlands with zeolite-containing filter sands. Bioresour. Technol., 102: 937-941.

Chen, Y., Y. W en, J. Cheng, C. Xue and D. Yang et al., 2011. Effects of dissolved Oxygen on extracellular enzymes activities and transformation of Carbon sources from plant biomass: Implications for denitrification in constructed wetlands. Bioresour. Technol., 102: 2433-2440.
Chen, Z.M., B. Chen, J.B. Zhou, Z. Li and Y. Zhou et al., 2008. A vertical subsurface-flow constructed wetland in Beijing. Commun. Nonlinear Sci. Numer. Simulation, 13: 1986-1997.

Cooper, P.F., 1996. Reed Beds and Constructed Wetlands for Wastewater Treatment. WRe Publications, Medmenham, Marlow, UK., ISBN:9781898920274, Pages: 184.

Ehrig, H.J. and R. Stegmann, 1992. Biological Processes. In: Landfilling of Waste: Leachate, Christensen, T.H., R. Cossu and R. Stegmann (Eds.). E. \& F.N. Spon Ltd., New York, USA., ISBN:0-419-161406, pp: 185-202.

Fountoulakis, M.S., S. Terzakis, A. Chatzinotas, H. Brix and N. Kalogerakis et al., 2009. Pilot-scale comparison of constructed wetlands operated under high hydraulic loading rates and attached biofilm reactors for domestic wastewater treatment. Sci. Total Environ., 407: 2996-3003.

Garcia, J., P. Aguirre, R. Mujeriego, Y. Huang and L. Ortiz et al., 2004. Initial contaminant removal performance factors in horizontal flow reed beds used for treating urban wastewater. Water Res., 38: 1669-1678.

Gikas, G.D., C.S. Akratos and V.A. Tsihrintzis, 2007. Performance monitoring of a vertical flow constructed wetland treating municipal wastewater. Global NEST. J., 9: 277-285.

Ho, Y.S. and G. McKay, 1999. Pseudo-second order model for sorption processes. Proces. Biochem., 34: 451-465.

Inamori, R., P. Gui, P. Dass, M. Matsumura and K.Q. Xu et al., 2007. Investigating $\mathrm{CH}_{4}$ and $\mathrm{N}_{2} \mathrm{O}$ emissions from eco-engineering wastewater treatment processes using constructed wetland microcosms. Process Biochem., 42: 363-373.

Jinadasa, K.B.S.N., N. Tanaka, S. Sasikala, D.R.I.B. Werellagama and M.I.M. Mowjood et al., 2008. Impact of harvesting on constructed wetlands performance-a comparison between Scirpus grossus and Typha angustifolia. J. Environ. Sci. Health Part A., 43: 664-671.

Kadlec, R.H. and R. Knight, 1996. Treatment Wetlands. Lewis Publishers, Boca Raton, Florida, Pages: 893.

Kadlec, R.H. and S. Wallace, 2009. Treatment Wetlands. 2nd Edn., Taylor and Francis Group, Boca Raton, Florida, USA., ISBN:978-1-56670-526-4, Pages: 366.

Kaseva, M.E., 2004. Performance of a sub-surface flow constructed wetland in polishing pre-treated wastewater-a tropical case study. Water Res., 38: 681 687. 
Klapper, H., 1992. Calcite Covering of Sediment as a Possible Way of Curbing Blue-Green Algae. In: Eutrophication: Research and Application to Water Supply, Sutcliffe, D.W. and J.G. Jones (Eds.). Freshwater Biological Association, Ambleside, UK., pp: 107-111.

Klomjek, P. and S. Nitisoravut, 2005. Constructed treatment wetland: A study of eight plant species under saline conditions. Chemosphere, 58: 585-593.

Korkusuz, E.A., M. Beklioglu and G.N. Demirer, 2004. Treatment efficiencies of the vertical flow pilot-scale constructed wetlands for domestic wastewater treatment. Turk. J. Eng. Environ. Sci., 28: 333-344.

Langergraber, G., D. Giraldi, J. Mena, D. Meyer and M. Pena et al., 2009. Recent developments in numerical modelling of subsurface flow constructed wetlands. Sci. Total Environ., 407: 3931-3943.

Lee, C.Y., C.C. Lee, F.Y. Lee, S.K. Tseng and C.J. Liao, 2004. Performance of subsurface flow constructed wetland taking pretreated swine effluent under heavy loads. Bioresour. Technol., 92: 173-179.

Lee, S., M.C. Maniquiz and L.H. Kim, 2010. Characteristics of contaminants in water and sediment of a constructed wetland treating piggery wastewater effluent. J. Environ. Sci., 22: 940-945.

Li, L., Y. Li, D.K. Biswas, Y. Nian and G. Jiang, 2008. Potential of constructed wetlands in treating the eutrophic water: Evidence from Taihu lake of China. Bioresour. Technol., 99: 1656-1663.

Lian-Sheng, H., L. Hong-Liang, X. Bei-Dou and Z. Ying-Bo, 2006. Effects of effluent recirculation in vertical-flow constructed wetland on treatment efficiency of livestock wastewater. Water Sci. Technol., 54: 137-146.

Luederitz, V., E. Eckert, M. Lange-Weber, A. Lange and R.M. Gersberg, 2001. Nutrient removal efficiency and resource economics of vertical flow and horizontal flow constructed wetlands. Ecol. Eng., 18: 157-171.

Mburu, N., S.M. Tebitendwa, D.P.L. Rousseau, J.J.A.V. Bruggen and P.N.L. Lens, 2012. Performance evaluation of horizontal subsurface flow-constructed wetlands for the treatment of domestic wastewater in the tropics. J. Environ. Eng., 139: 358-367.

Obarska-Pempkowiak, H. and K. Klimkowska, 1999. Distribution of nutrients and heavy metals in a constructed wetland system. Chemosphere, 39: 303-312.

Reed, S.C., 1993. Subsurface Flow Constructed Wetlands for Wastewater Treatment: A Technology Assessment. West Virginia University, Morgantown, West Virginia,.
Ruan, X., Y. Xue, J. Wu, L. Ni and M. Sun et al., 2006. Treatment of polluted river water using pilot-scale constructed wetlands. Bull. Environ. Contam. Toxicol., 76: 90-97.

Rudzinski, W. and W. Plazinski, 2007. Studies of the kinetics of solute adsorption at solid/solution interfaces: On the possibility of distinguishing between the diffusional and the surface reaction kinetic models by studying the pseudo-first-order kinetics. J. Phys. Chem. C., 111: 15100-15110.

Sim, Ch.H., M.K. Yusoff, B. Shutes, S. Ch.Ho and M. Mansor, 2007. Nutrient removal in a pilot and full scale constructed wetland, Putrajaya city, Malaysia. J. Environ. Manage., 88: 307-317.

Tangahu, B.V., S.R.S. Abdullah, H. Basri, M. Idris and N. Anuar et al., 2013. Phytotoxicity of wastewater containing lead $(\mathrm{Pb})$ effects Scirpus grossus. Intl. J. Phytorem., 15: 814-826.

Tseng, R.L., F.C. Wu and R.S. Juang, 2010. Characteristics and applications of the Lagergren's first-order equation for adsorption kinetics. J. Taiwan Inst. Chem. Eng., 41: 661-669.

Vieira, R.H. and B. Volesky, 2000. Biosorption: A solution to pollution? Int. Microbiol., 3: 17-24.

Vymazal, J., 2005. Horizontal sub-surface flow and hybrid constructed wetlands systems for wastewater treatment. Ecol. Eng., 25: 478-490.

Vymazal, J., 2007. Removal of nutrients in various types of constructed wetlands. Sci Total Environ., 380: 48-65.

Vymazal, J., M. Greenway, K. Tonderski, H. Brix and U. Mander, 2006. Constructed Wetlands for Wastewater Treatment. In: Wetlands and Natural Resource Management, Verhoeven, J.T.A., B. Beltman, R. Bobbink and D.F. Whigham (Eds.). Springer, Berlin, Germany, ISBN:978-3-540-33186-5, pp: 69-96.

Wang, L.K., J.H. Tay, S.T.L. Tay and Y.T. Hung, 2010. Environmental Bioengineering. Vol. 11, Humana Press, New York, USA., ISBN:978-1-58829-493-7, Pages: 867.

Wittgren, H.B. and T. Maehlum, 1997. Wastewater treatment wetlands in cold climates. Water Sci. Technol., 35: 45-53.

Xinshan, S., L. Qin and Y. Denghua, 2010. Nutrient removal by hybrid subsurface flow constructed wetlands for high concentration ammonia nitrogen wastewater. Procedia Environ. Sci., 2: 1461-1468.

Yuan, H.P., J.H. Zhang, Z.M. Lu, H. Min and C. Wu, 2009. Studies on biosorption equilibrium and kinetics of $\mathrm{Cd}^{2+}$ by Streptomyces sp. K33 and HL-12. J. Hazard. Mater., 164: 423-431. 